\title{
Paisajes tópicos Del lugar común a los lugares comunes en la fotografía contemporánea (chilena)
}

\author{
Nathalie Goffard ${ }^{1}$
}

Recepción: 12 de marzo de 2018 / Aceptación: 6 de agosto de 2018

\section{Resumen}

Este ensayo tiene como propósito especular sobre las correspondencias semánticas entre las nociones de "lugar" y "lugar común" ocupando la fotografía de paisaje como hilo conductor. Más específicamente, se expone que los cambios de paradigmas estéticos en la fotografía contemporánea son reactivos y dialogan con los otros usos sociales de la fotografía y en este caso, el turismo. Asimismo, se plantea que dichas relaciones se han ido complejizando en un contexto de mayor mercantilización y patrimonialización del paisaje, llevando a los artistas a optar por representar lugares banales. Para ello, se alude a la idea de fotografía estereotipada de paisaje típico en analogía con la figura del lugar común, para formular la hipótesis de cómo la sobreproducción visual afecta la renovación del imaginario paisajístico. Finalmente, esta relación es problematizada en el contexto de las artes visuales chilenas para concluir que el paisaje es ante todo un artefacto cultural dinámico que varía conforme mutan las miradas.

\section{Palabras clave}

Fotografía contemporánea; teoría del paisaje; cultural visual; turismo; Chile

\section{Abstract}

The aim of this essay is to speculate on the semantic correspondences between the notions of "place" and "common place" engaging landscape photography as a common thread. Specifically, it is exposed that the changes of aesthetic paradigms in contemporary photography are reactive and dialogue with the other social uses of photography, and in this case tourism. Furthermore it suggests that these relationships have become more complex in a context of greater commercialization and patrimonialization of the landscape, leading artists to prefer to represent banal places. In this line, the idea of stereotyped photography of typical landscape is suggested to analogy with the figure of the commonplace, to formulate the hypothesis of how visual overproduction affects the renewal of the landscape imaginary. In sum, this relationship is problematized in the context of the Chilean visual arts to conclude, that the landscape is first and foremost a dynamic cultural artefact that varies complain the becoming beside the point of view.

1 Chilena. Magíster en Investigación en Artes Plásticas por la Universidad París 1 Panthéon-La Sorbonne, Francia. Doctoranda en Filosofía con mención en Estética y Teoría del Arte, Universidad de Chile. Correo electrónico: ngoffardster@gmail.com 


\section{Keywords}

Contemporary photography; landscape theory; visual culture; tourism; Chile

\section{Resumo}

O objetivo deste ensaio é indagar sobre as correspondências semânticas entre as noções de "lugar" e "lugar comum" tendo como fio condutor a fotografia de paisagem. Mais especificamente, expõe-se que as mudanças de paradigmas estéticos na fotografia contemporânea são reativas e dialogam com os demais usos sociais da fotografia e, neste caso, o turismo. Sugere-se também que tais relações se complexificaram num contexto de maior mercantilização e patrimonialização da paisagem, levando aos artistas a optarem por representar lugares banais. Para tanto, alude-se à ideia de fotografia estereotipada de paisagem típica em analogia à figura do lugar comum, para formular a hipótese de como a superprodução visual afeta a renovação do imaginário paisagístico. Finalmente, essa relação é discutida no contexto das artes visuais chilenas para concluir que a paisagem é, antes de tudo, um artefato cultural dinâmico que varia na medida em que mudem os olhares.

\section{Palavras chave}

Fotografia contemporânea; teoria da paisagem; cultura visual, turismo; Chile

\section{Introducción}

Es evidente que nada de aquello a que estamos acostumbrados nos emociona. Un poema debe ser algo inhabitual, pero hecho a base de cosas que manejamos constantemente, de cosas que están cerca de nuestro pecho, pues si el poema inhabitual también se halla construido a base de elementos inhabituales, nos asombrará más que emocionarnos.

Lo que asombra no transporta, no eleva el espíritu hasta las alturas del vértigo consciente.

Hay que ser un verdadero poeta para poder dar a las cosas que se hallan cerca de nosotros la carga suficiente para que nos maravillen; hay que ser poeta para enhebrar las palabras cotidianas en un filamento osram incandescente, y para que esta luminosidad interna caldee el alma en las latitudes a que se nos precipita

(Vicente Huidobro, Manifiesto de Manifiestos).

El lugar común es una expresión formularia basada en aserciones ya convenidas y asentadas. Asimismo, refiere a una idea que se ha vuelto trivial debido a su excesivo uso. De carácter repetitivo, el lugar común se asocia en términos de significado al cliché y estereotipo, pero no siempre fue así... irónicamente, incluso la noción de lugar común sufrió su propio desgaste y cristalización, deviniendo a su vez un lugar común. En efecto, tendemos a olvidar que en la Antigüedad clásica, los lugares comunes formaban parte 
de la tópica (de topikos, relativo al lugar) y que, en la retórica aristotélica, eran entendidos como un conjunto de tópicos que servían al orador para desarrollar y exponer sus argumentos. Estos topoi koinoi constituían una suerte de fondo común disponible de ideas admitidas y comprobadas, una suerte de repertorio prefijado susceptible de ser utilizado en el discurso². "Los topoi, integrados a la inventio (o búsqueda de ideas), primera parte del trabajo del orador, no son sólo un método de razonamiento, sino que además se transforman en una reserva de argumentos tipos" (Amossy y Herschbert, 2010, p. 20).

El uso peyorativo del lugar común es algo relativamente reciente. Se inicia en la Edad Media y se vuelve predominante en el siglo XVIII: "Io tópico se transforma en típico, en reservorio de tipos, se cristalizan y convierten en estereotipos" (Compagnon, 1979, citado por Amossy y Herschbert, 2010, p. 20). Ahora, en términos de continuum cultural e histórico no es de extrañar que siempre ocurran aquellas paulatinas degradaciones e hipertrofias del sentido: las ideas se gastan y desgastan con el paso del tiempo y por exceso de uso. Conforme los saberes se van acumulando, se solapan sobre otros antecedentes, se divulgan y repiten hasta volverse comunes. La novedad de las ideas es efímera; la originalidad inestable y contextual. Bien lo afirmaba Remy de Gourmont al decir que "la imitación es la mancha inevitable y terrible que acecha a los libros demasiado felices; lo que fue original y fresco parece una colección ridícula de pájaros embalsamados; las imágenes nuevas se transforman en clichés" (de Gourmont, 1899, citado por Amossy y Herschbert, 2010, p. 13). Mas, un lugar común no es precisamente un cliché, aún menos un estereotipo. Tanto el primero como el tópico hacen referencia al lenguaje y las ideas, a desgastes verbales y conceptuales. En cambio, los clichés y estereotipos -cuyos orígenes semánticos remiten al campo de la gráfica y la reproducción en serie $^{3}$ - si bien pueden asociarse a frases o expresiones, se vinculan más bien con el mundo de las representaciones y apariencias. El cliché puede ser exagerado o erróneo; el lugar común, en su versión contemporánea, es una "frase hecha" o un conocimiento sobreutilizado, pero siempre parte de una premisa verdadera, de Gourmont decía:

El lugar común es más y menos que una banalidad: es una banalidad, pero a veces ineludible; es una banalidad, pero tan universalmente aceptada que toma el nombre de verdad. La mayor parte de las verdades que corren por el mundo (las verdades son buenas corredoras) pueden ser vistas como lugares comunes, es decir asociaciones de ideas comunes a un gran número de hombres, que casi ninguno de esos hombres osaría quebrar de manera deliberada (1983, p. 24).

2 Los Tópicos de Aristóteles están articulados en ocho libros, específicamente, del libro II al VII se enuncia, analiza y define los diferentes tipos de lugares comunes para el estudio de la dialéctica que permite una forma de razonamiento basado en el conocimiento probable (Aristóteles, 1982).

3 Estereotipo viene de la estereotipia, el cual, en las artes gráficas, es un procedimiento para reproducir una composición tipográfica sobre una plancha firme, presionándola contra cartones o láminas de otra materia que sirven a su vez de molde para vaciar el metal fundido. El cliché es una tira de película fotográfica revelada, con imágenes en negativo, para su posterior reproducción en papel o una plancha tipográfica en la que se ha reproducido una composición o un grabado para su posterior impresión. 
Por ejemplo, comenzar una oración con "desde todos los tiempos el hombre ha buscado la felicidad" es un lugar común pero no así un error; decir "los latinos son alegres y ruidosos" es un cliché que a su vez apela a estereotipos ${ }^{4}$ étnicos y culturales. Estereotipar guarda relación tanto con un entendimiento simplificado de los otros como con percepciones rígidas e imágenes estructuradas que asociamos a determinados grupos humanos, anulando su individualidad. Son de hecho "creencias sobre las clases de individuos, de grupos o de objetos, que son preconceptos, es decir, que no responden a una apreciación nueva de cada fenómeno, sino a hábitos de pensamiento y expectativas habituales" (Jahoda, 1964, citado por Amossy y Herschbert, 1990, p. 32).

El cliché tiene, en cierto sentido, un carácter más peyorativo y negativo en cuanto a que generalmente se asoma en bocas de quienes buscan emitir opiniones o juicios estéticos sobre algo. Es de hecho, el adjetivo que recurrentemente utilizamos para calificar y cuestionar la calidad de determinadas creaciones o producciones. Así, hablamos de escenas o historias "clichés" en películas o libros y sobre todo, cuando nos referimos a la publicidad y la moda, cuyas imágenes rebozan de lugares y personajes de ese tipo. Por ejemplo, una escena cliché sería mencionar que los funerales cinematográficos ocurren siempre bajo una plétora de paraguas negros un día de lluvia, cuando en realidad la gente también muere los días de excesivo calor. En otras palabras, si al estereotipo se le atribuye una excesiva simplificación o exageración por desconocimiento de lo particular, al cliché se le reprocha su falta de originalidad y creatividad. Todo pasa como si para que existiera un cliché tuviera primero que antecederle múltiples lugares comunes. El lugar común, entonces, es en cierta forma el grado cero del cliché; una versión menos acumulativa y palimpséstica de hipertrofia y desgaste conceptual. Entonces, lugar común sería "todos moriremos algún día”, cliché "todos moriremos un día lluvioso".

Cabe preguntarse si en una época regida por la velocidad, la hipercirculación de la información y la transferencia expedita de saberes, la novedad y originalidad no son acaso cada vez más difíciles de sostener en el tiempo. En la era actual, caracterizada por la sobreproducción y el solapamiento de imaginarios, el lapso de tiempo transcurrido entre sobreuso y agotamiento del sentido de una idea parece acortarse cada vez más. En efecto, en el mundo de las imágenes y las representaciones, la brecha temporal entre asimilación, instalación y deslucimiento posiblemente nunca había sido tan veloz. Un buen ejemplo de aquella aceleración en el proceso de inflación-deflación de sentido, ha sucedido durante estas últimas décadas con la noción de paisaje en el campo de la fotografía contemporánea. En otras palabras, con aquello que califica (o no) para ser representado y valorado como paisaje. Bien lo asevera

$4 \quad$ El estereotipo como concepto aparece recién en el siglo XX, convirtiéndose en objeto de interés para las ciencias sociales y su estudio permite desde el campo de la cognición, analizar y comprender cómo las ideas preconcebidas, las creencias e incluso, desde una arista negativa, los prejuicios son impuestos por diferentes patrones culturales. 
Thierry Paquot (2016) al decir que tanto "lo bello" como "lo feo" no solo pertenecen al registro de lo estético sino que también corresponden a valores colectivos y modelos dominantes vehiculados por todo un aparato ideológico (p. 4). Asimismo, parafraseando a Alain Roger (2007), podríamos aseverar que el proceso de "artealisación"5 del territorio -algo así como su devenir-paisajese ha ido complejizando y precipitando. Cada vez más lugares "aplican" para ser considerados paisajes en el arte contemporáneo, pero, por otro lado, sus fechas de caducidad se van acortando, encaminándose hacia el cliché. En otras palabras, si la montaña y el mar tuvieron que esperar hasta el siglo XIX para ser valorados como paisajes, hoy devienen rápidamente marinas de "pintor de domingo" o bienes de consumo de tienda de souvenir; los despoblados y las carreteras, en cambio, no tardaron más de cincuenta años en asimilarse a un imaginario paisajístico.

Las nuevas configuraciones geográficas, económicas y sociales ocupan un lugar primordial en la fotografía contemporánea. Las transformaciones del territorio han sido dignas de interés para artistas y fotógrafos quienes han sido en gran parte responsables de mostrarnos el potencial fotográfico de la arquitectura estandarizada, zonas inhospitalarias, lugares de tránsito y áreas suburbanas (Goffard, 2013, p. 173).

El paisaje no existe, se crea. Dicho ad nauseam por expertos y estudiosos del tema, el definirlo como un constructo cultural dinámico que muta conforme cambian las sociedades y sus representaciones está en camino a convertirse en un lugar común. De cierta forma, la definición de paisaje es un tópico en el sentido aristotélico, en la medida en que forma parte de un fondo común de ideas eficientes, un conocimiento admitido y usado para la elaboración de discursos -ya convenido por especialistas y conocedores del tema-. No obstante, cabe notar que no será cuestión aquí de esto, sino más bien de preguntarse si las imágenes -y no solo la idea- de los paisajes que entendemos como "típicos" corresponden a tópicos aristotélicos, en cuanto a verdades admitidas (endoxa) o si justamente, producto de sus excesivas representaciones, califican cada vez más para ser lugares comunes, ideas gastadas. ¿Puede un paisaje típico ${ }^{6}$ ser considerado como un lugar común? Convengamos en que el paisaje solo existe por la mirada de quien lo contempla y que irónicamente, los lugares comunes son todo menos lugares físicos. Mas, como mencionábamos anteriormente, los gustos cambian y las ideas se agotan, así como sus representaciones. ¿Podríamos entonces

$5 \quad$ La artealisación es un neologismo acuñado por Roger en su libro Breve tratado del paisaje. Tiene dos formas: in situ y in visu. La primera es la intervención directa del humano en el territorio, la segunda es hecha a distancia, cuando la mirada (consciente o inconscientemente) se impregna de modelos perceptivos (pictóricos, literarios, fotográficos, etcétera) que la van modelando (Roger, 2007).

6 Se entenderá aquí paisaje típico como un lugar que destaca por su belleza singular y característica. Según la UNESCO, la zonas típicas y pintorescas destacan por tener una armonía ambiental de conjunto y poseen una especial connotación histórica, estética, constructiva, natural, arqueológica, entre otros. Recuperado de http://www.unesco.org/culture/natlaws/media/pdf/chile/chil_normas_ zonas_pitorescas_spaorof.pdf 
asumir un inevitable volverse lugar común de la imagen-paisaje, con la gran contradicción que de hecho lo terminan padeciendo aquellos lugares que justamente no son comunes?

Un paisaje es un tópico en cuanto a que apela simultáneamente a una experiencia nueva y al reconocimiento de algo familiar, a la asimilación de un tipo. Al respecto, Berque afirma que un paisaje tiene un componente original pero también algo de "siempre ya visto" y solo toma forma cuando el distanciamiento es acompañado de proyección (1989, p. 25). El paisaje es entonces una experiencia de reconocer y re-conocer: "On ne voit que ce qui a déjà été vu, et on le voit comme il doit être vu" [Solo se ve lo que ya ha sido visto, y se ve como debe ser visto] (Cauquelin, 2000, p. 84). En efecto, no podemos nombrar, identificar y valorar el paisaje si no hemos aprendido a definirlo como tal; si no hemos adiestrado la mirada a través de un palimpsesto de saberes y experiencias de nuestra memoria colectiva e individual. Bien lo decía Goethe "El simple mirar una cosa no nos permite avanzar. Cada mirar se muta en un considerar, cada considerar en un reflexionar, en un enlazar. Se puede decir que teorizamos en cada mirada atenta al mundo" (citado por Milani, 2007, p. 23). Mas, los modelos perceptivos que van modelando el paisaje no solo son inconscientes y endógenos, subjetivos y estéticos; la mirada paisajística se puede condicionar externa y pragmáticamente.

Hoy más que nunca, el paisaje posee tanto una dimensión cultural como un valor mercantil que permiten valorizarlo desde una perspectiva estrictamente económica y turística. Vivimos en la era de la imagen. Las fotografías o películas promocionales inducen y condicionan la percepción común hasta convertirse, como dice Vecchio (2009), en auténticos "a priori kantianos". En otras palabras:

Visualización inducida lo denomina Nogué (2007), quien reconoce que hoy los paisajes contemplados que tienen éxito son aquellos cuyas imágenes han sido previamente difundidas por la televisión, los suplementos de periódicos, las revistas de viajes o las fotografías de los turoperadores. Un fenómeno no enteramente nuevo, ya que desde hace mucho tiempo las guías turísticas, cuando proporcionan información paisajística suelen ser muy dirigistas: indican los mejores lugares de contemplación, lo que debe verse, lo que debe pensarse e incluso lo que debe sentirse (Laplace, 2007) (Corbera, 2016, p. 20).

Para Corbera (2016), de hecho, los verdaderos artializadores - parafraseando a Roger- son los expertos que deciden qué cualidades o valores debe tener un paisaje para que otorgue beneficios económicos. En ese sentido, la patrimonialización del paisaje juega un papel fundamental no solo como instrumento de poder para la construcción identitaria, sino también para la economía de un país. Los paisajes son, en efecto, ordenados, regulados, 
turistificados ${ }^{7}$ e incluso rankeados en pos de resguardarlos como bienes patrimoniales y promoverlos como, valga la redundancia, bienes de consumo.

El turismo es una industria, pero también es un instrumento fundamental para la elaboración de imaginarios e identidades nacionales. Entonces, "preguntarse cómo se construye un paisaje nacional significa preguntarse por cómo este se presenta (en texto e imágenes)" (Ahumada, 2013, p. 114). Y como las representaciones actuales son esencialmente producidas por los medios de comunicación y la publicidad, a su vez difundidas protagónicamente por internet, para continuar esta discusión cabría entonces comentar la siguiente anécdota:

Al hacer el ejercicio de buscar en la red el título del presente ensayo, "paisaje tópico", Google Imágenes replicó: "quiso decir paisaje típico" (Figura 1). Omitiendo aquel consejo del buscador, las imágenes resultantes se resumieron básicamente siempre a las mismas: lugares pintorescos de carta postal, campos floridos sin identidad, escenas bucólicas dignas de banco de imágenes: pinturas de casas campestres, fotografías de cascadas, campos cultivados, valles fértiles y panorámicas de ciudades. Un "paisaje tópico" por razones obvias no existe, pero para Google, uno genéricamente típico tampoco, al estar este adjetivo siempre yuxtapuesto a un lugar geográfico: "paisajes de Toscana, mediterráneos, sanjuaninos, etc.". Se completó entonces el ejercicio de búsqueda con la palabra "Chile" y Google Imágenes mostró lo siguiente: Moais de la Isla de Pascua; la Patagonia y las Torres del Paine; diversos bosques de araucarias, árboles autóctonos y característicos del sur de Chile; cascadas y volcanes nevados de la misma zona del país (Figura 2).

Figura 1. Pantallazo búsqueda en google "paisajes tópicos".

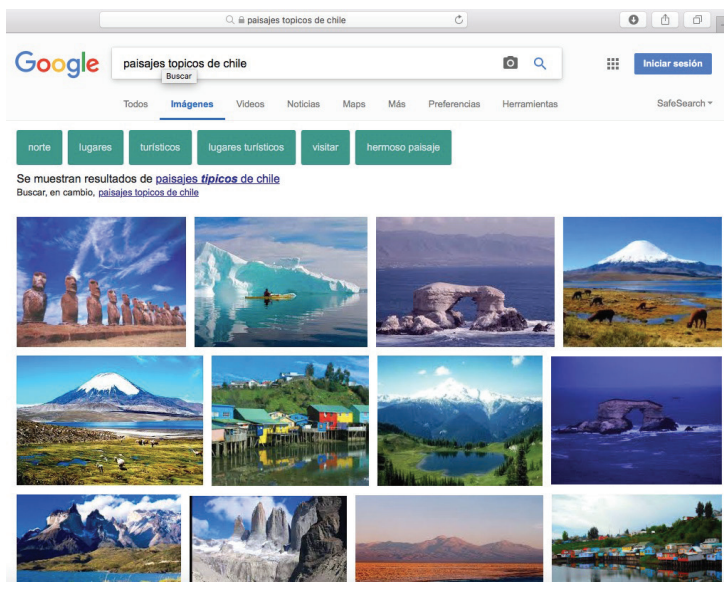

Fuente: Google.

$7 \quad$ Melina Piglia detalla que la turistificación del territorio es un "proceso de valorización turística de un espacio, proceso en el que intervienen e interactúan las dimensiones materiales (la producción del espacio), simbólicas (la construcción de representaciones o invención del lugar) y territoriales (dimensión del poder)" (2007, p. 132) (Cf. Zusman, Lois y Castro, 2008). 
Figura 2. Volcán Llaima Copyright @ 2004-2018.

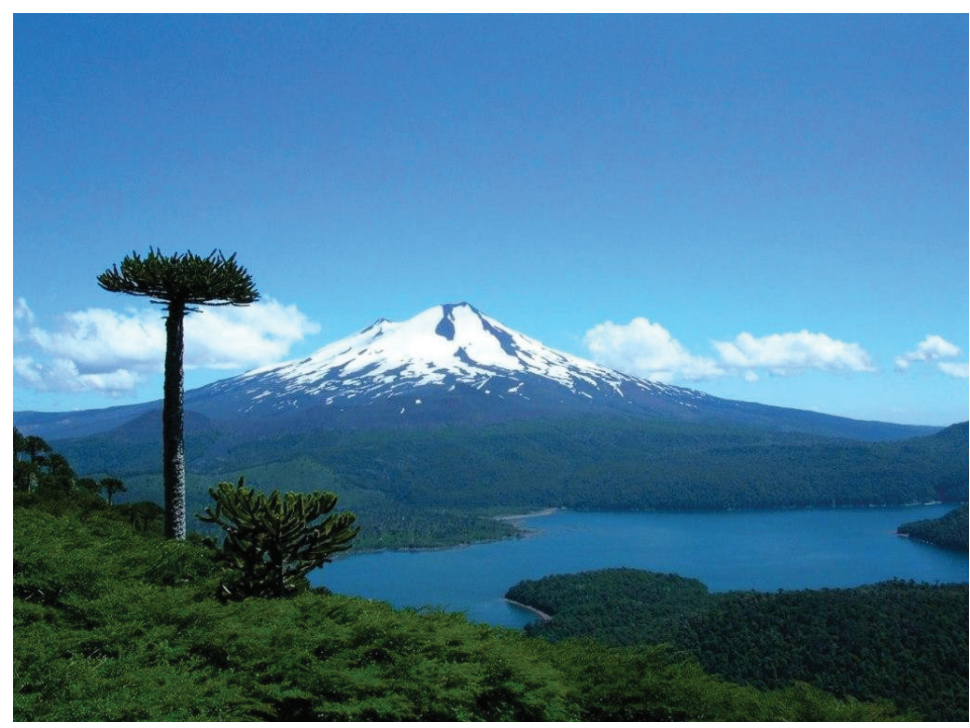

Fuente: Fonditos Fondos de pantalla Fondos de escritorio gratis http://www.fonditos.com.

Chile es el país más largo del mundo con 4329 km de longitud que equivalen a la décima parte de la circunferencia de la Tierra y, básicamente, tiene dos fronteras naturales: el Océano Pacífico y la Cordillera de Los Andes. Las costas chilenas tienen una extensión de más de 8000 km y además, el desierto de Atacama, el más árido del mundo, cubre una superficie de aproximadamente $105000 \mathrm{~km}^{2}$. Llama entonces la atención que en ese recuento virtual del buscador tanto playas como desiertos o páramos sean minoritarios en aquella representación de la imagen país. Como bien lo asevera Ahumada (2014), las representaciones del paisaje en Chile se han caracterizado por la omnipresencia de la cordillera por sobre el mar como metáfora de lo chileno, donde "la montaña sirve como un motivo útil para dar unidad al proyecto de nación que se construye desde la ciudad de Santiago como capital, y desde la elite criolla" (p. 114). Sucede lo mismo con la predominancia del sur de Chile por sobre el norte. Esto porque durante el siglo XX existió una política general de promoción del Sur por parte de la Empresa de Ferrocarriles Del Estado, a cargo de la organización, producción y difusión del turismo y en cuyas propagandas turísticas asociadas al viaje en tren, dominaban lagos, ríos o volcanes. Booth (2008) afirma que mediante la Guía de Veraneante (Figura 3), revista editada por la Empresa de Ferrocarriles del Estado entre 1932 y 1962, "la organización turística estatal y su aparato de propaganda, propiciaron la conversión de extensos territorios vacíos en paisajes turísticos para la mayoría de los chilenos" (p. 1). En efecto, las representaciones iconográficas de dicha revista, en gran parte centradas en escenas del sur de Chile, reconfiguraron el imaginario paisajístico nacional reduciéndolo a un repertorio alusivo a una suerte de "Suiza chilena". El Norte 
en cambio, resumido a la aridez del desierto, al parecer sin atractivo turístico y casi sin sistema ferroviario, no fue promocionado hasta fines del siglo XX. Asimismo, sucedió con los hielos milenarios, fiordos y canales de la Patagonia ${ }^{8}$.

Figura 3. Portada Revista Guía del veraneante, 1951.

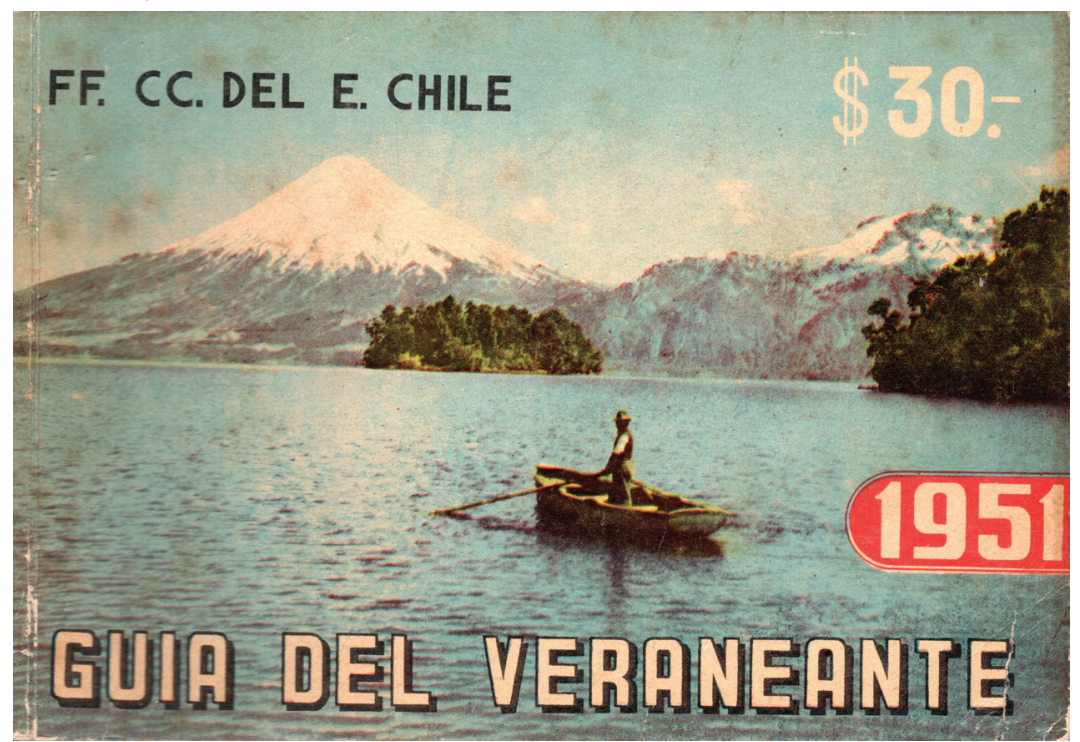

Fuente: Guía del veraneante: revista de turismo de los FF.CC. del E. (Chile)/ Empresa de los Ferrocarriles del Estado, 1951.

Los lectores habrán entendido que Chile es un territorio de paisajes contrastados, de glaciares y geiseres, volcanes y valles, arideces y humedales, bosques y playas, acantilados y pampas. A ratos las postales del país parecen una versión salvaje de los fiordos nórdicos, otras, una versión tercermundista de Suiza o, eventualmente, podrían asemejarse a una versión altiplánica del imaginario polvoriento vehiculado por la estética cinematográfica del Viejo Oeste estadunidense. Todos y cada uno de estos lugares han inundado las páginas de folletos turísticos, portafolios de fotógrafos, calendarios y rompecabezas, páginas de libros institucionales, exposiciones itinerantes, ilustraciones de manuales escolares y coffee table books locales hasta en cierta medida agotar su representación. La movilidad y el turismo son esenciales en la constitución del imaginario paisajístico, pero históricamente también han colaborado para su construcción, artistas, cineastas y escritores, quienes ahora parecen no interesarse en el pintoresquismo del paisaje. Todo pasa como si la estética difundida por Sernatur ${ }^{9}$ hubiera terminado por banalizar lugares a priori únicos,

$8 \quad$ No corresponde aquí extenderse en un análisis sociológico, económico y político, pero la promoción y difusión de los paisajes extremos de Chile a partir de fines del siglo XX guarda tanto relación con cuestiones geopolíticas y de soberanía, como con las diferencias existentes entre turismo local versus extranjero, de clase media versus de elite, entre otros.

9 Es la sigla con la que se conoce el Servicio Nacional de Turismo chileno. 
convirtiéndolos en lugar común, llevando a los artistas a buscar novedad y originalidad en lugares comunes.

Ahora bien, como lo afirmaba de Gourmont (1983), los lugares comunes son portadores de verdad, verdades desgastadas y sobre-representadas pero verdades al fin. Bajo esa misma perspectiva, los artistas Peter Fischli y David Weiss, entrevistados a propósito de su obra "Visible World"10 y con respecto al hecho de fotografiar "bellas flores", ponen en cuestión el hecho de si ¿podríamos mirar alguna vez de nuevo los hitos paisajísticos y del turismo como si fuera la primera vez?

Can I restore my innocence? You go to the beautiful beach, palm trees, sunset, you take a photo; on the one hand you think it's great, but in the back of your mind you know these pictures are very corny. But the pathos is there [¿Puedo restaurar mi inocencia? Vas a hermosas playas, palmeras, puestas de sol, tomas fotos; por un lado piensas que es increíble, pero en el fondo tú sabes que esas imágenes son muy cursis. Pero el pathos está ahí] (Heiser, $1^{\circ}$ de octubre 2006).

En otra entrevista, Fischli y Weiss aseveran con respecto a este tipo de lugar que lo más interesante es situarse en un intermedio entre el artista y el turista, porque para ellos las imágenes críticas son tan fáciles de hacer como los clichés. Por esto mismo, podría afirmarse que la postura de la dupla de artistas guarda más relación con reencontrar y reconciliarse con lo que alguna vez fue un lugar común, una premisa verdadera que perdió su brillo pero que aún fascina que, con el hecho de simular o criticar el paisaje convertido en bien de consumo.

And the 'critical' image doesn't explain the fascination of the Pyramids in any case. There is a reason why the Pyramids are famous. When you go there, no matter how many photographs you've seen of them, you realize that the pyramids are unique, and you don't understand them. There is a reason why these sites are powerful; there's a reason why the waves in the sea are emotionally attractive, and we wanted to explore these images, knowing that they were in some way forbidden fruits [En ningún caso la imagen crítica explica la fascinación por las Pirámides. Hay una razón por la cual las pirámides son famosas. Cuando vas ahí, no importa cuántas fotografías hayas visto de ellas, te das cuenta que las pirámides son únicas y no las entiendes. Hay una razón por la cual estos sitios son poderosos; hay una razón por la cual las olas en el mar son emocionalmente atractivas, y queríamos explorar esta imagen, sabiendo que de alguna manera son frutos prohibidos] (Bishop y Godfrey, 2006, párr. 20).

La fotografía está intrínsecamente ligada al turismo, la movilidad y el viaje -un trío cada vez menos indisociable- y a la conformación de un archivo visual cada vez más saturado. No obstante, incluso en la era de la muerte del exotismo acuñada por Marc Augé (1997), donde pareciera que ya no

10 Esta obra (1987-2007) es una instalación exhibida en cajas de luces y en video, que reúne 3000 fotografías del mundo entero. Destacan en la serie, hitos del turismo de masas, como el Times Square de Nueva york, los canales de Venecia, diversas puestas de sol, entre otros. 
queda nada por descubrir, cuando el mismo autor afirma que los turistas solo transforman en imágenes un mundo que ya lo es: no importa cuántas fotografías hayan sido tomadas antes de nuestra presencia en un lugar o que hayamos visto miles de imágenes anteriores, seguimos sacándolas una y otra vez. De hecho, el viaje de reconocimiento del paisaje existe desde el siglo XVIII. El paisaje como objeto de búsqueda y motivo de viaje empieza a articularse en la época del Grand Tour, cuando la élite, sobre todo británica, se desplazaba para reconocer los paisajes que había visualizado anteriormente en obras de arte. Dos siglos después, el viaje de reconocimiento y la experiencia paisajística persisten, aunque las imágenes parecen agotarse, o por lo menos para las artes visuales, porque "de hecho, el siglo XX ha llenado nuestra memoria visual con imágenes de lugares recónditos, paisajes espectaculares difundidos tanto a través del ámbito editorial y publicitario como las prácticas amateur, llevándonos a una sobreproducción y consumo de imágenes" (Goffard, 2013, p. 171).

Durante estas últimas tres décadas, se ha generado una apertura temática y visual de la fotografía en el campo del arte. Son imágenes que preferentemente se sitúan al "ras" de la realidad, sin anécdota, redimiendo lo banal en sí mismo. Es así como lo espectacular dio paso a lo "ya visto mil veces": aeropuertos, estaciones de trenes, carreteras, balnearios, cadenas hoteleras, parques de atracciones, estacionamientos, arquitecturas de barrios periféricos, condominios en barrios residenciales, centros de deportes, centros comerciales, supermercados, terrenos en construcción, etcétera. A partir de la década de $1990^{11}$, todo se volvió susceptible de ser paisaje. Si bien esto venía gestándose desde los años 60 con las neovanguardias artísticas, el paisaje tuvo que esperar a que terminaran los años 80, el remezón del VIH, las teorías de género y postcoloniales, para volver a ser un tópico de interés, digno de reflexiones y revisiones. En Chile se tuvo que esperar más: en plena dictadura militar (1973-1989), la escena artística local desarrollaba una neo-vanguardia sui generis y la fotografía documental, por su parte, cumplía funciones de denuncia y resistencia en las calles... el paisaje como género cayó entonces en desuso.

El paisaje común empezó a ser trabajado por el artista Enrique Zamudio (n. 1955) en la década de 1980, primero utilizando foto-emulsiones fotográficas para registrar la ciudad de Santiago vacía por el toque de queda impuesto por el régimen dictatorial; luego, centrándose en el imaginario de la zona central de Chile, plasmado en fotografías en 3D de un desatendido y poco valorado

11 A grandes rasgos, este fenómeno tiene como principales exponentes a los artistas-fotógrafos alemanes provenientes de la escuela de Dusserdolf, alumnos de los esposos Bernd e Hilla Becher, como Andreas Gursky, Thomas Struth, entre otros. En Estados Unidos esa relación con el "paisaje común" es anterior y en gran parte inspirada por artistas como Edward Rusha y Lewis Baltz y por la tradición fotográfica norteamericana del "paisaje vernáculo": los New Color Photographers y los New Topographics representados por William Eggleston y Stephen Shore, entre otros. 
árbol Espino ${ }^{12}$ (Figura 4) y en imágenes en blanco y negro de las turbulentas olas del Pacífico (Figura 5). Zamudio inaugura en Chile la era del paisaje banal. En efecto, la fastuosidad de los paisajes nacionales, a medio camino entre el fantasma de la terra incognita y el exotismo enigmático, han sido material fértil para la industria del turismo y para una experiencia postindustrial de lo sublime y no así para una renovación visual y temática de la fotografía de paisaje -en cuanto a creación artística- reduciendo el género a un mero espectáculo estético; una anécdota documental que dice: mira este paisaje que lindo es. ¿Podría ser de otro modo? Aún más en este rincón del planeta, donde todavía sobreviven parajes únicos en apariencia poco tocados por el ser humano. Parafraseando al poeta Robert Walser, los bellos paisajes son como la felicidad, no son un material fértil para los creadores, demasiado autosuficientes.

Figura 4. Enrique Zamudio, P 05, de la serie Paisaje 3D, 2011.

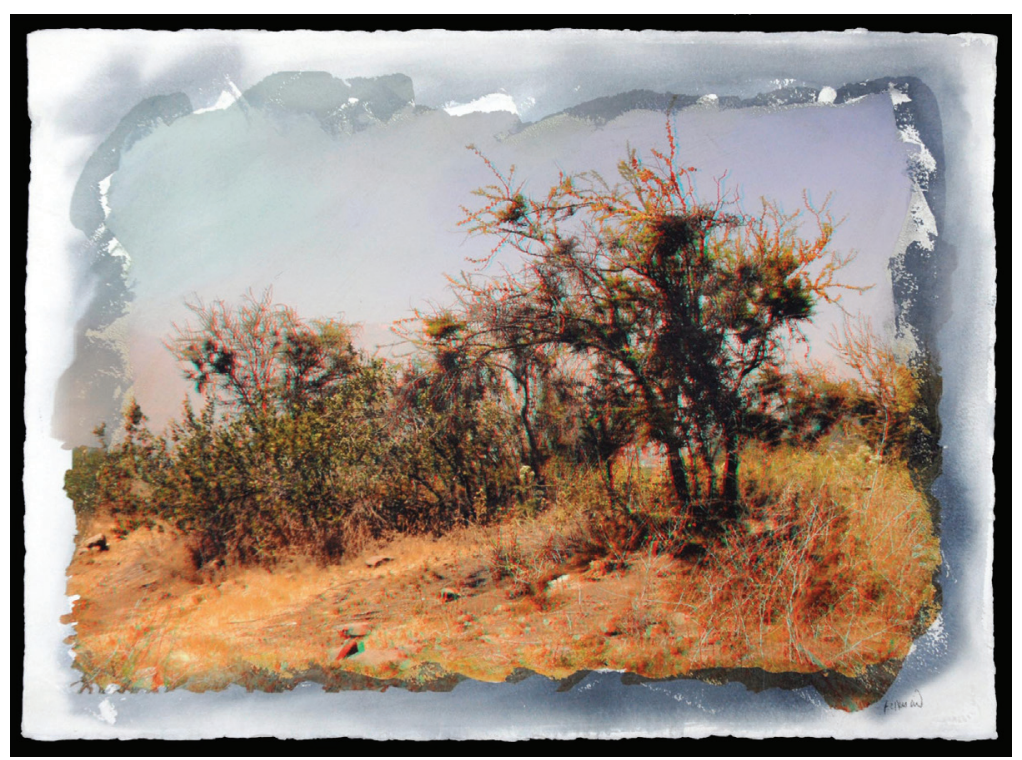

Fuente: Cortesía del artista.

12 El Espino (Acacia caven) es uno de los árboles característicos del bosque esclerófilo del valle central de Chile. De lento crecimiento y alta resistencia, ciertamente menos glamoroso que la Araucaria, estuvo a punto de extinguirse debido a su tala constante para obtener leña y elaborar carbón, debido a su buena capacidad calórica. 
Figura 5. Enrique Zamudio, 16, de la serie Ola, 2007.

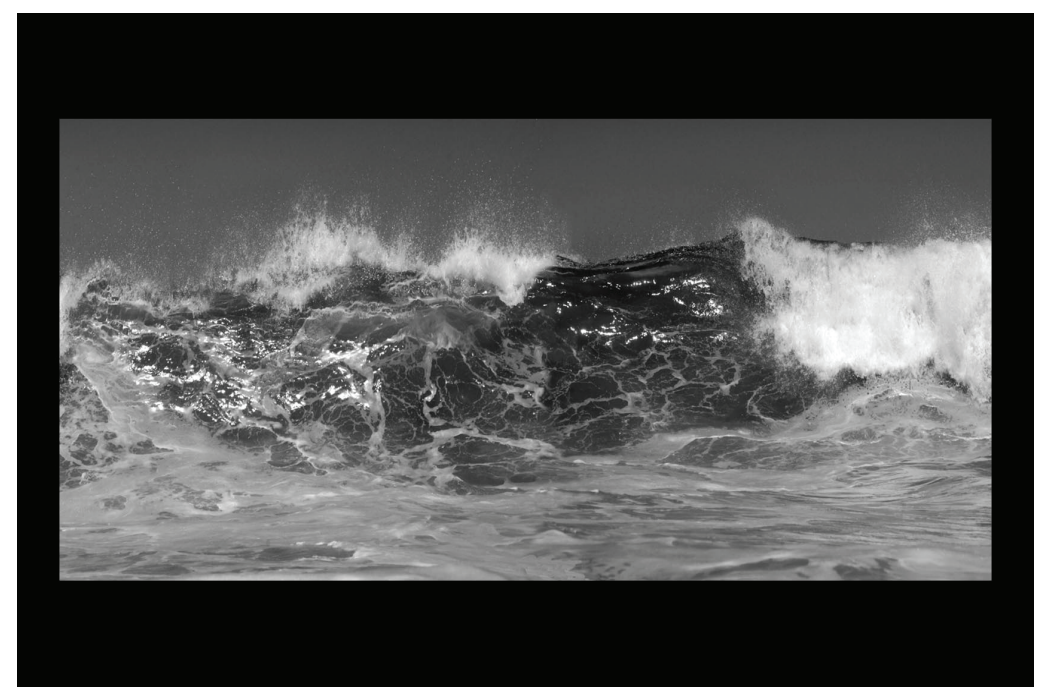

Fuente: Cortesía del artista.

Después de 20 años, las nuevas generaciones de fotógrafos y artistas han empezado a interesarse en los paisajes comunes de Chile, aquellos explotados y sobreexplotados, habitados y habituales, invasivos e invisibles. Entre estos destacan las vistas aéreas de Santiago de Chile que Francisca Montes (n. 1980) saca desde una avioneta, hace siete años, todos los $1^{\circ}$ de mayo y 11 de septiembre, días de manifestaciones y feriados que provocan desplazamientos de masas humanas en el espacio urbano (Figura 6). Asimismo, Montes se interesa por el registro del río Maipo $^{13}$ y cómo este configura la geografía humana de la región que lo alberga (Figura 7). Sebastián Mejía (n. 1982) por su parte, indaga sobre la sobrevivencia de la vegetación en la ciudad, la adaptación inoportuna de las palmeras (Figura 8) y recupera el deambular urbano como acto creativo para crear composiciones abstractas a partir de lo ínfimo (Figura 9). Podemos también mencionar, de forma general, los paisajes nocturnos de cotidiana ruralidad de Fernando Melo (n. 1964); las lagunas artificiales y los hitos del turismo local de Nicolás Rupcich (n. 1981); los bailarines de carnaval puestos en escena en basurales del desierto de Demian Schopf (n. 1975); las construcciones precarias y formas residuales de Cristián Silva-Avaria (n. 1975); entre otros.

13 El río Maipo da origen a la principal hoya hidrográfica de la Región Metropolitana de Santiago. La cuenca del Maipo presenta una alta concentración poblacional e industrial, lo que genera problemas de crecidas y contaminación. Es el principal colector de la aguas de esa región, concentrando el 70 $\%$ de la demanda de agua potable y aproximadamente el $90 \%$ de aguas de regadío. 
Figura 6. Francisca Montes, $1^{\circ}$ de Mayo 2012, fotografía digital impresa en inyección de tinta, $130 \mathrm{~cm}$. x 85 cm., 2013.

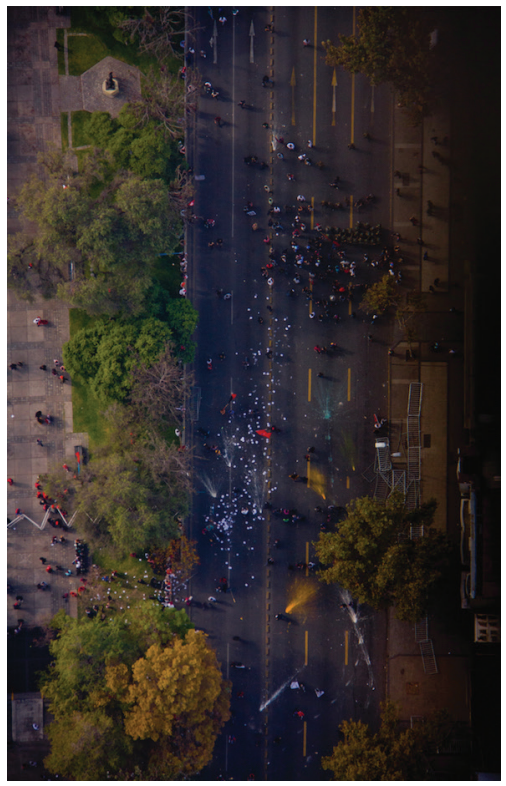

Fuente: Cortesía de la artista.

Figura 7. Francisca Montes, Rio Maipo, Still de Película en 4K, 90 minutos, 2017.

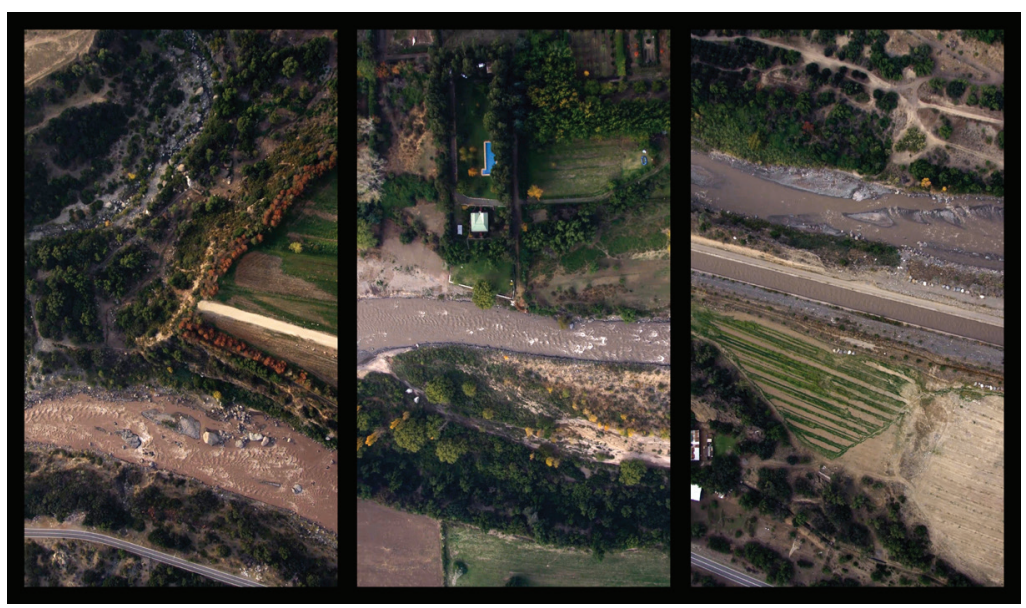

Fuente: Cortesía de la artista. 
Figura 8. Sebastián Mejía, Palma Patronato, de la serie "Revisited", 100 × 80 cm, 2015 .

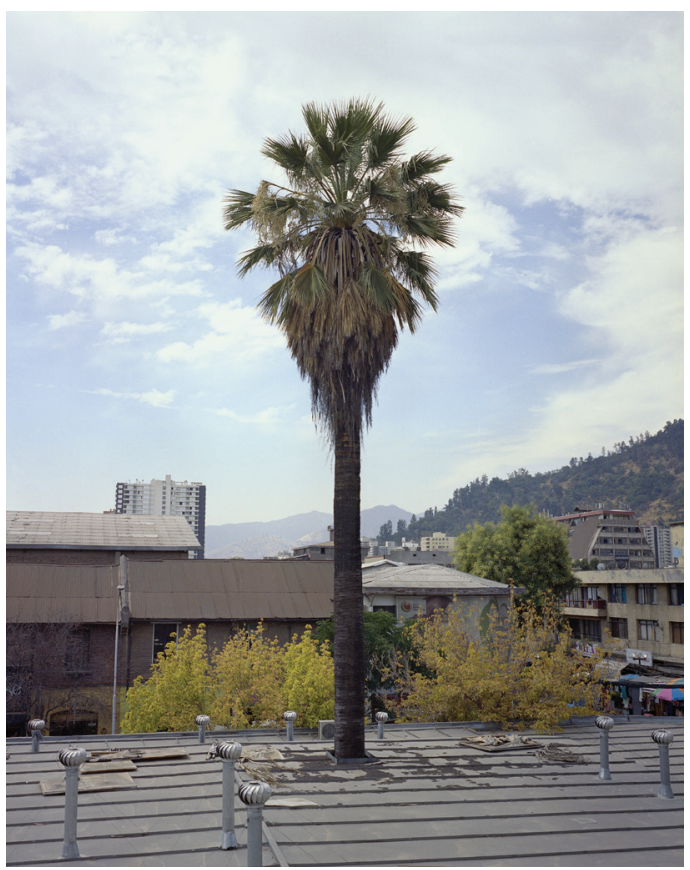

Fuente: Cortesía del artista.

Figura 9. Sebastián Mejía, Ventana, de la serie "Expediciones", 40 x 54 cm., 2011.

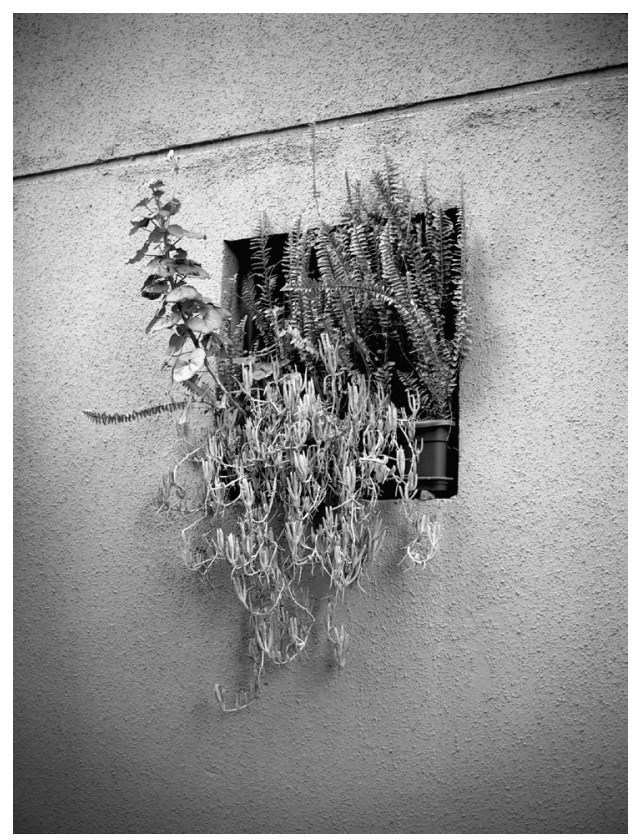

Fuente: Cortesía del artista. 
Sea un síntoma o una reacción al imaginario monopolizado por los medios masivos y la industria del turismo, a la estetización del mundo vía los filtros de los iPhone y de Instagram, a los fondos de pantalla y bancos de imágenes, a la espectacularidad de la fotografía patrimonial de los coffee tables books, incluso a la masificación de la fotografía -hoy en día todo el mundo puede ser fotógrafo-, el interés por lo cotidiano por parte de los artistas parece ser un fenómeno mundial. El mundo es tomado tal y como es, con sus degradaciones ambientales, sus recursos privatizados y sobreexplotados, su crecimiento desmedido y sus territorios sobre-vigilados a la vez que sobreexpuestos y estandarizados.

Vivimos en tiempos donde el "nunca visto" de la sociedad industrial ha dado paso al "siempre ya visto" de la era de la información. Es como si nuestras miradas estuvieran saturadas por la sobreabundancia de imágenes y no se necesitara más imágenes nuevas, originales o insólitas. Mientras más se perfeccionan las tecnologías que sobrepasan los límites de lo visible, más virtual se vuelve la realidad que nos proyecta a lugares cada vez más lejanos; más parece que nos replegamos en lo irrisorio y lo banal como forma de resistencia frente a la pérdida de la creencia en la realidad.

Ahora, como bien lo dice el epígrafe que inicia este ensayo, "hay que ser un verdadero poeta para poder dar a las cosas que se hallan cerca de nosotros la carga suficiente para que nos maravillen". Lo que queda por saber es: ¿aquellos lugares comunes predilectos del arte contemporáneo sufrirán una aceleración en su devenir lugar común? Si las puestas de sol, las escenas pastorales y las vistas panorámicas de valles, todos alguna vez considerados como paisajes idílicos -locus amoenus - tardaron un par de siglos en desgastarse, las carreteras y suburbios reducirán sin duda su proceso de corrosión iconográfica. Primero, cabría preguntarse si alguna vez estos paisajes lograrán establecerse como verdades convenidas en el imaginario paisajístico. Ya sabemos que, en palabras de Remy de Gourmont, el lugar común es una banalidad que inevitablemente toma el nombre de verdad y que el paisaje, entendido como verdad, es una buena corredora, que muta y de adapta a las sociedades que lo piensan y crean.

\section{Referencias}

Ahumada, Paulina. (2014). Paisaje y Nación: la majestuosa montaña en el imaginario del siglo XIX. En A. Peliowski y C. Valdés (Eds.). Una geografía imaginada. Diez ensayos sobre arte y naturaleza. Santiago: Ediciones Metales Pesados-Ediciones Universidad Alberto Hurtado.

Amossy, Ruth y Herschbert, Anne. (2010). Estereotipos y clichés. Buenos Aires: Eudeba.

Aristóteles. (1982). Tratados de la lógica: (organon). Madrid: Serie Biblioteca clásica Gredos, 51. Gredos. 
Augé, Marc. (1997). L'impossible voyage. Le tourismo et ses images. París: Rivages Poche.

Berque, Augustin. (1989). Les milles naissances du paysages. En H. François y B. Latarjet (Dir.). Paysages photographies, en France les années quatrevingt. La Mission Photographique de la DATAR (1984-1989). (pp. 21-49). París: Editions Hazan.

Bishop, Claire; Godfrey, Marc. (2006). Between spectacular and ordinary, Flashart, 251, Noviembre-diciembre. Recuperado de https://www. flashartonline.com/article/fischli-and-weiss/

Booth, Rodrigo. (2008). Turismo y representación del paisaje. La invención del sur de Chile en la mirada de la Guía del Veraneante (1932-1962). Nuevo Mundo Mundos Nuevos. DOI: 10.4000/nuevomundo.25052

Cauquelin, Anne. (2000). L'invention du paysage. París: PUF.

Corbera Millán, Manuel. (2016). El paisaje, su patrimonalización y el beneficio económico. Investigaciones Geográficas, 65, 9-24. DOI: http://dx.doi. org/10.14198/INGEO2016.65.01

Goffard, Nathalie. (2013). Imagen criolla. Prácticas fotográficas en las artes visuales de Chile. Santiago: Metales pesados.

de Gourmont, Remy. (1983 [1900]). La Culture des idées. París: Société du Mercure de France.

Heiser, Jörg. (1º de octubre 2006). The Odd Couple. Frieze. Recuperado de https://frieze.com/article/odd-couple

Huidobro, Vicente. (2003). Obra Poética. Madrid: ALLCA XX.

Milani, Raffaele. (2007). El arte del paisaje. Madrid: Biblioteca Nueva.

Paquot, Thierry. (2016). Le paysage. París: La Découverte.

Régine, Pietra. (1987). Lieux communs. Littérature. Espaces et Chemins, 65, 96-108. DOI: 10.3406/litt.1987.1420

Roger, Alain. (2007). Breve tratado del paisaje. Madrid: Biblioteca Nueva.

Zusman, Perla; Lois, Carla y Castro, Hortensia. (2008). Viajes y geografías: Exploraciones, turismo y migraciones en la construcción de lugares. Buenos Aires (Argentina): Prometeo Libros. 
Para ampliar la información sobre las trayectorias de los fotógrafos puede consultar:

Cristián Silva-Avária. Recuperado de http://www.silva-avaria.com Demian Schopf. Recuperado de https://www.demianschopf.com

Francisca Montes. Dieecke.cl. Recuperado de http://www.dieecke.cl/artistas/ francisca-montes\#1\#imagenes

Enrique Zamudio. Recuperado de www.enriquezamudio.cl Nicolas Rupcich. Recuperado de www.nicolasrupcich.com 